\title{
Synthesis, Characterization and Crystal Structures of Cobalt(II), Zinc(II) and Cadmium(II) Complexes Derived from 2-Hydroxy-N'-(pyridin-2-ylmethylene)benzohydrazide with Antimicrobial Activity
}

\author{
Li-Hang Wang, ${ }^{1}$ Xiao-Yang Qiu ${ }^{1,2, \star}$ and Shu-Juan Liu ${ }^{1}$ \\ ${ }^{1}$ College of Science \& Technology, Ningbo University, Ningbo 315212, P.R. China \\ ${ }^{2}$ State Key Laboratory of Structural Chemistry, Fujian Institute of Research on the Structure of Matter, Chinese Academy of \\ Sciences, Fuzhou, Fujian 350002, P.R. China \\ *Corresponding author: E-mail: xiaoyang_qiu@126.com
}

Received: 03-08-2019

\begin{abstract}
Three new cobalt(II), zinc(II) and cadmium(II) complexes, [ $\left.\mathrm{CoL}_{2}\right] \cdot 2 \mathrm{CH}_{3} \mathrm{OH} \cdot \mathrm{H}_{2} \mathrm{O}(\mathbf{1})$, $\left[\mathrm{ZnL}_{2}\right](2)$ and $\left[\mathrm{Cd}\left(\mathrm{HL}_{2}\left(\mathrm{NO}_{3}\right)\right]\right.$ $\mathrm{N}_{3}$ (3), were prepared from 2-hydroxy- $N$ '-(pyridin-2-ylmethylene)benzohydrazide (HL). The complexes have been characterized by IR, UV-Vis and single-crystal X-ray diffraction techniques. X-ray analysis indicates that the complexes are mononuclear species, with the metal atoms in octahedral coordination. The hydrazone compound and its complexes were evaluated for their antibacterial (Bacillus subtilis, Staphylococcus aureus, Escherichia coli, and Pseudomonas fluorescence) and antifungal (Candida albicans and Aspergillus niger) activities. The complexes have effective activities against the bacteria.
\end{abstract}

Keywords: Hydrazone; Mononuclear complex; Crystal structure; Antimicrobial activity

\section{Introduction}

Hydrazones are a kind of Schiff base compounds, bearing typical functional group, $\mathrm{CH}=\mathrm{N}-\mathrm{NH}-\mathrm{C}(\mathrm{O})$. Compounds have attracted tremendous attention due to their interesting and versatile biological properties like antibacterial, ${ }^{1}$ antifungal, ${ }^{2}$ as well as antitumor. ${ }^{3}$ Cobalt, zinc and cadmium complexes derived from Schiff base ligands have been widely studied for their potential antibacterial activities. ${ }^{4}$ As a further exploration of novel complex based antimicrobial agents, in the present work, three new cobalt(II), zinc(II) and cadmium(II) complexes, $\left[\mathrm{CoL}_{2}\right]$. $2 \mathrm{CH}_{3} \mathrm{OH} \cdot \mathrm{H}_{2} \mathrm{O}(\mathbf{1}),\left[\mathrm{ZnL}_{2}\right](2)$ and $\left[\mathrm{Cd}(\mathrm{HL})_{2}\left(\mathrm{NO}_{3}\right)\right] \mathrm{N}_{3}$ (3), respectively, where Lis the anion of 2-hydroxy- $N^{\prime}$-(pyridin-2-ylmethylene)benzohydrazide (HL; Scheme 1), are presented.<smiles>O=C(N/N=C/c1ccccn1)c1ccccc1O</smiles>

Scheme 1. HL

\section{Experimental}

\section{1. Materials and Instruments}

All the organic compounds and inorganic salts with AR grade were obtained from Sigma-Aldrich and used without further purification. The ligand HL was prepared according to the literature mthod. ${ }^{5}$ Elemental analyses $(\mathrm{C}, \mathrm{H}, \mathrm{N})$ were carried out with a Perkin-Elmer 2400II analyzer. FT-IR spectra were recorded on a Perkin-Elmer 377 spectrometer with $\mathrm{KBr}$ pellets. UV-Vis spectra were recorded on a Lambda 900 spectrometer. ${ }^{1} \mathrm{H}$ and ${ }^{13} \mathrm{C}$ NMR data were recorded on a Bruker $500 \mathrm{MHz}$ spectrometer. X-ray diffraction was carried out on a Bruker APEX II CCD diffractometer.

\section{2. Synthesis of Complex 1}

$\mathrm{HL}(1.0 \mathrm{mmol}, 0.24 \mathrm{~g})$ and $\mathrm{Co}\left(\mathrm{NO}_{3}\right)_{2} \cdot 6 \mathrm{H}_{2} \mathrm{O}(1.0$ $\mathrm{mmol}, 0.29 \mathrm{~g}$ ) were dissolved in $50 \mathrm{~mL} \mathrm{MeOH}$. The mixture was heated to reflux for $1 \mathrm{~h}$. Then, it was cooled to room temperature. Single crystals of the complex were generated after 5 days following the slow evaporation of the solvent. Yield 27\%. IR data $\left(\mathrm{cm}^{-1}\right): 3454(\mathrm{OH}), 1600$ $(\mathrm{C}=\mathrm{N})$. UV-Vis data $\left(\mathrm{CH}_{3} \mathrm{OH}, \lambda_{\max }, \mathrm{nm}\right): 276,380,390$. 
Elemental analysis found: $\mathrm{C}, 54.25 ; \mathrm{H}, 4.72 ; \mathrm{N}, 13.46 \%$, $\mathrm{C}_{26} \mathrm{H}_{20} \mathrm{CoN}_{6} \mathrm{O}_{4} \cdot 2 \mathrm{CH}_{3} \mathrm{OH} \cdot \mathrm{H}_{2} \mathrm{O}$ calcd: $\mathrm{C}, 54.11 ; \mathrm{H}, 4.87$; $\mathrm{N}, 13.52 \%$.

\section{3. Synthesis of Complex 2}

$\mathrm{HL}(1.0 \mathrm{mmol}, 0.24 \mathrm{~g})$ and $\mathrm{Zn}\left(\mathrm{CH}_{3} \mathrm{COO}\right)_{2} \cdot 2 \mathrm{H}_{2} \mathrm{O}$ $(1.0 \mathrm{mmol}, 0.22 \mathrm{~g})$ were dissolved in $50 \mathrm{~mL} \mathrm{MeOH}$. The mixture was heated to reflux for $1 \mathrm{~h}$. Then, it was cooled to room temperature. Single crystals of the complex were generated after 7 days following the slow evaporation of the solvent. Yield $45 \%$. IR data $\left(\mathrm{cm}^{-1}\right): 3450(\mathrm{OH}), 3387$ $(\mathrm{NH}), 1596(\mathrm{C}=\mathrm{N})$. UV-Vis data $\left(\mathrm{CH}_{3} \mathrm{OH}, \lambda_{\max }, \mathrm{nm}\right): 269$, 305,323 , 370. Elemental analysis found: $\mathrm{C}, 57.38 ; \mathrm{H}, 3.77$; $\mathrm{N}, 15.26 \%, \mathrm{C}_{26} \mathrm{H}_{20} \mathrm{~N}_{6} \mathrm{O}_{4} \mathrm{Zn}$ calcd: C, 57.21; H, 3.69; N, $15.40 \%$.

\section{4. Synthesis of Complex 3}

HL (1.0 mmol, $0.24 \mathrm{~g}), \mathrm{NaN}_{3}(1.0 \mathrm{mmol}, 0.065 \mathrm{~g})$ and $\mathrm{Cd}\left(\mathrm{NO}_{3}\right)_{2} \cdot 4 \mathrm{H}_{2} \mathrm{O}(1.0 \mathrm{mmol}, 0.31 \mathrm{~g})$ were dissolved in $50 \mathrm{~mL} \mathrm{MeOH}$. The mixture was heated to reflux for $1 \mathrm{~h}$. Then, it was cooled to room temperature. Single crystals of the complex were generated after 3 days following the slow evaporation of the solvent. Yield $33 \%$. IR data $\left(\mathrm{cm}^{-}\right.$ $\left.{ }^{1}\right)$ : $3450(\mathrm{OH}), 2072\left(\mathrm{~N}_{3}\right), 1638(\mathrm{C}=\mathrm{O}), 1601(\mathrm{C}=\mathrm{N}), 1456$, 1311, $1072\left(\mathrm{NO}_{3}\right)$. UV-Vis data $\left(\mathrm{CH}_{3} \mathrm{OH}, \lambda_{\max }, \mathrm{nm}\right): 280$, 368. Elemental analysis found: $\mathrm{C}, 44.52 ; \mathrm{H}, 3.31 ; \mathrm{N}$, 19.92\%, $\mathrm{C}_{26} \mathrm{H}_{22} \mathrm{CdN}_{10} \mathrm{O}_{7}$ calcd: $\mathrm{C}, 44.68 ; \mathrm{H}, 3.17 ; \mathrm{N}$, $20.04 \%$

\section{5. X-ray Crystallography}

The collected data were reduced with SAINT, ${ }^{6}$ and multi-scan absorption correction was applied by using SADABS. ${ }^{7}$ Structures of the three complexes were solved by direct method and refined against $F^{2}$ by full-matrix least-squares method with SHELXTL. ${ }^{8}$ The non-hydrogen atoms were refined anisotropically. The hydroxyl and amino hydrogen atoms were located from electronic density maps and refined isotropically. The remaining hydrogen atoms were placed in calculated positions and constrained to ride on their parent atoms. The atoms O5, O6, O7, C27 and C28 of the solvent molecules in complex $\mathbf{1}$, and the azide anion in complex $\mathbf{2}$ are disordered, which were refined with isotropic behavior. The hydrogen atoms of the disordered methanol molecules in complex $\mathbf{1}$ are not added, but included in the formula. The crystallographic data and refinement parameters for the compounds are listed in Table 1. Selected bond lengths and angles are listed in Table 2 .

\section{Results and Discussion}

\section{1. Chemistry}

HL was prepared from the condensation reaction of 2-pyridinecarboxaldehyde with 2-hydroxybenzohydrazide in $\mathrm{MeOH}$. The complexes were prepared from the self-assembly of hydrazone compound with cobalt nitrate, zinc acetate, and cadmium nitrate and sodium azide, respec-

Table 1. Crystallographic and refinement data for HL and its metal complexes.

\begin{tabular}{|c|c|c|c|c|}
\hline & HL & 1 & 2 & 3 \\
\hline Formula & $\mathrm{C}_{13} \mathrm{H}_{11} \mathrm{~N}_{3} \mathrm{O}_{2}$ & $\mathrm{C}_{28} \mathrm{H}_{28} \mathrm{CoN}_{6} \mathrm{O}_{7}$ & $\mathrm{C}_{26} \mathrm{H}_{20} \mathrm{~N}_{6} \mathrm{O}_{4} \mathrm{Zn}$ & $\mathrm{C}_{26} \mathrm{H}_{22} \mathrm{CdN}_{10} \mathrm{O}_{7}$ \\
\hline Formula weight & 241.25 & 618.49 & 545.85 & 698.94 \\
\hline$T(\mathrm{~K})$ & $298(2)$ & $298(2)$ & $298(2)$ & $298(2)$ \\
\hline Crystal system & Monoclinic & Monoclinic & Monoclinic & Monoclinic \\
\hline Space group & $P 2_{1} / c$ & $P 2_{1} / n$ & $C 2 / c$ & $P 2 / n$ \\
\hline$a(\AA)$ & $4.8050(6)$ & $11.208(1)$ & $18.215(2)$ & $13.056(2)$ \\
\hline$b(\AA)$ & $22.413(3)$ & $18.930(2)$ & $24.601(2)$ & $8.275(1)$ \\
\hline$c(\AA)$ & $10.875(2)$ & $13.124(2)$ & $11.556(1)$ & $13.056(2)$ \\
\hline $\mathrm{b}\left({ }^{\circ}\right)$ & $102.399(2)$ & $98.426(2)$ & $103.588(2)$ & $104.100(3)$ \\
\hline$V\left(\AA^{3}\right)$ & $1143.8(3)$ & $2754.4(5)$ & $5033.2(9)$ & $1368.1(4)$ \\
\hline$Z$ & 4 & 4 & 8 & 2 \\
\hline$D_{\text {calc }}\left(\mathrm{g} \mathrm{cm}^{-3}\right)$ & 1.401 & 1.491 & 1.441 & 1.697 \\
\hline$\mu(\mathrm{Mo} \mathrm{Ka})\left(\mathrm{mm}^{-1}\right)$ & 0.098 & 0.682 & 1.020 & 0.865 \\
\hline$F(000)$ & 504 & 1280 & 2240 & 704 \\
\hline Measured reflections & 10430 & 15995 & 13037 & 5483 \\
\hline Unique reflections & 2026 & 5124 & 4588 & 2038 \\
\hline Observed reflections $(I \geq 2 \sigma(I))$ & 1388 & 4299 & 3057 & 1427 \\
\hline Parameters & 167 & 381 & 340 & 205 \\
\hline Restraints & 1 & 32 & 2 & 14 \\
\hline GOF on $F^{2}$ & 1.032 & 1.116 & 0.993 & 1.015 \\
\hline$R_{1}, w R_{2}[I \geq 2 \sigma(I)]^{a}$ & $0.0468,0.0953$ & $0.0700,0.2230$ & $0.0496,0.1254$ & $0.0535,0.1302$ \\
\hline$R_{1}, w R_{2}(\text { all data })^{a}$ & $0.0819,0.1124$ & $0.0806,0.2345$ & $0.0786,0.1436$ & $0.0853,0.1435$ \\
\hline
\end{tabular}

Wang et al.: Synthesis, Characterization and Crystal Structures of ... 
Table 2. Selected bond distances $(\AA)$ and angles $\left(^{\circ}\right)$ for the complexes

\begin{tabular}{|c|c|c|c|}
\hline \multicolumn{4}{|c|}{1} \\
\hline $\mathrm{Co}(1)-\mathrm{O}(1)$ & $1.905(3)$ & $\mathrm{Co}(1)-\mathrm{O}(3)$ & $1.923(3)$ \\
\hline $\mathrm{Co}(1)-\mathrm{N}(1)$ & $1.926(4)$ & $\operatorname{Co}(1)-\mathrm{N}(2)$ & $1.856(4)$ \\
\hline $\mathrm{Co}(1)-\mathrm{N}(4)$ & $1.933(4)$ & $\mathrm{Co}(1)-\mathrm{N}(5)$ & $1.852(4)$ \\
\hline $\mathrm{N}(5)-\mathrm{Co}(1)-\mathrm{N}(2)$ & $178.44(18)$ & $\mathrm{N}(5)-\mathrm{Co}(1)-\mathrm{O}(1)$ & $96.03(16)$ \\
\hline $\mathrm{N}(2)-\mathrm{Co}(1)-\mathrm{O}(1)$ & $82.50(16)$ & $\mathrm{N}(5)-\mathrm{Co}(1)-\mathrm{O}(3)$ & $82.26(16)$ \\
\hline $\mathrm{N}(2)-\mathrm{Co}(1)-\mathrm{O}(3)$ & $97.18(16)$ & $\mathrm{O}(1)-\mathrm{Co}(1)-\mathrm{O}(3)$ & $89.85(14)$ \\
\hline $\mathrm{N}(5)-\mathrm{Co}(1)-\mathrm{N}(1)$ & $98.42(17)$ & $\mathrm{N}(2)-\mathrm{Co}(1)-\mathrm{N}(1)$ & $83.04(17)$ \\
\hline $\mathrm{O}(1)-\mathrm{Co}(1)-\mathrm{N}(1)$ & $165.49(16)$ & $\mathrm{O}(3)-\mathrm{Co}(1)-\mathrm{N}(1)$ & $90.71(16)$ \\
\hline $\mathrm{N}(5)-\mathrm{Co}(1)-\mathrm{N}(4)$ & $82.78(17)$ & $\mathrm{N}(2)-\mathrm{Co}(1)-\mathrm{N}(4)$ & $97.76(17)$ \\
\hline $\mathrm{O}(1)-\mathrm{Co}(1)-\mathrm{N}(4)$ & $91.27(16)$ & $\mathrm{O}(3)-\mathrm{Co}(1)-\mathrm{N}(4)$ & $165.04(16)$ \\
\hline $\mathrm{N}(1)-\mathrm{Co}(1)-\mathrm{N}(4)$ & $91.93(17)$ & & \\
\hline \multicolumn{4}{|c|}{2} \\
\hline $\mathrm{Zn}(1)-\mathrm{O}(1)$ & $2.162(3)$ & $\mathrm{Zn}(1)-\mathrm{O}(3)$ & $2.110(2)$ \\
\hline $\mathrm{Zn}(1)-\mathrm{N}(1)$ & $2.230(3)$ & $\mathrm{Zn}(1)-\mathrm{N}(2)$ & $2.052(3)$ \\
\hline $\mathrm{Zn}(1)-\mathrm{N}(4)$ & $2.265(3)$ & $\mathrm{Zn}(1)-\mathrm{N}(5)$ & $2.047(3)$ \\
\hline $\mathrm{N}(5)-\mathrm{Zn}(1)-\mathrm{N}(2)$ & $169.45(10)$ & $\mathrm{N}(5)-\mathrm{Zn}(1)-\mathrm{O}(3)$ & $75.49(9)$ \\
\hline $\mathrm{N}(2)-\mathrm{Zn}(1)-\mathrm{O}(3)$ & $115.05(9)$ & $\mathrm{N}(5)-\mathrm{Zn}(1)-\mathrm{O}(1)$ & $105.23(9)$ \\
\hline $\mathrm{N}(2)-\mathrm{Zn}(1)-\mathrm{O}(1)$ & $74.78(10)$ & $\mathrm{O}(3)-\mathrm{Zn}(1)-\mathrm{O}(1)$ & $93.20(11)$ \\
\hline $\mathrm{N}(5)-\mathrm{Zn}(1)-\mathrm{N}(1)$ & $105.21(10)$ & $\mathrm{N}(2)-\mathrm{Zn}(1)-\mathrm{N}(1)$ & 75.15(11) \\
\hline $\mathrm{O}(3)-\mathrm{Zn}(1)-\mathrm{N}(1)$ & $95.16(11)$ & $\mathrm{O}(1)-\mathrm{Zn}(1)-\mathrm{N}(1)$ & $149.55(9)$ \\
\hline $\mathrm{N}(5)-\mathrm{Zn}(1)-\mathrm{N}(4)$ & $74.64(10)$ & $\mathrm{N}(2)-\mathrm{Zn}(1)-\mathrm{N}(4)$ & $94.81(10)$ \\
\hline $\mathrm{O}(3)-\mathrm{Zn}(1)-\mathrm{N}(4)$ & $149.95(9)$ & $\mathrm{O}(1)-\mathrm{Zn}(1)-\mathrm{N}(4)$ & $91.46(10)$ \\
\hline $\mathrm{N}(1)-\mathrm{Zn}(1)-\mathrm{N}(4)$ & $95.71(11)$ & & \\
\hline \multicolumn{4}{|c|}{3} \\
\hline $\mathrm{Cd}(1)-\mathrm{N}(1)$ & $2.379(6)$ & $\mathrm{Cd}(1)-\mathrm{O}(3)$ & $2.396(5)$ \\
\hline $\mathrm{Cd}(1)-\mathrm{N}(2)$ & $2.417(5)$ & & \\
\hline $\mathrm{N}(1)-\mathrm{Cd}(1)-\mathrm{N}(1 \mathrm{~A})$ & $101.9(3)$ & $\mathrm{N}(1)-\mathrm{Cd}(1)-\mathrm{O}(3 \mathrm{~A})$ & $149.79(19)$ \\
\hline $\mathrm{N}(1)-\mathrm{Cd}(1)-\mathrm{O}(3)$ & $105.20(18)$ & $\mathrm{O}(3)-\mathrm{Cd}(1)-\mathrm{O}(3 \mathrm{~A})$ & $53.2(2)$ \\
\hline $\mathrm{N}(1)-\mathrm{Cd}(1)-\mathrm{N}(2 \mathrm{~A})$ & $95.1(2)$ & $\mathrm{N}(1)-\mathrm{Cd}(1)-\mathrm{N}(2)$ & $67.7(2)$ \\
\hline $\mathrm{O}(3)-\mathrm{Cd}(1)-\mathrm{N}(2 \mathrm{~A})$ & $122.10(19)$ & $\mathrm{O}(3)-\mathrm{Cd}(1)-\mathrm{N}(2)$ & $83.20(18)$ \\
\hline $\mathrm{N}(1)-\mathrm{Cd}(1)-\mathrm{N}(2 \mathrm{~A})$ & $95.08(19)$ & $\mathrm{O}(3)-\mathrm{Cd}(1)-\mathrm{N}(2 \mathrm{~A})$ & $122.10(19)$ \\
\hline $\mathrm{N}(2)-\mathrm{Cd}(1)-\mathrm{N}(2 \mathrm{~A})$ & $153.3(3)$ & & \\
\hline
\end{tabular}

tively, in $\mathrm{MeOH}$. The $\mathrm{C}, \mathrm{H}, \mathrm{N}$ content determined from the elemental analyses agree well with those determined by single-crystal X-ray diffraction techniques.

\section{2. IR Spectra}

The weak and broad absorptions centered at 3420$3454 \mathrm{~cm}^{-1}$ are attributed to the stretching vibration of the $\mathrm{O}-\mathrm{H}$ bonds. The sharp bands observed at $3241 \mathrm{~cm}^{-1}$ of $\mathrm{HL}$ and at $3387 \mathrm{~cm}^{-1}$ of complex 3 are attributed to the stretching vibration of the amino $\mathrm{N}-\mathrm{H}$ bonds. The strong bands at $1628 \mathrm{~cm}^{-1}$ of the hydrazone $\mathrm{HL}$ and at $1638 \mathrm{~cm}^{-1}$ of complex 3 are due to the $v(\mathrm{C}=\mathrm{O})$ stretching vibrations, and the bands at $1596-1607 \mathrm{~cm}^{-1}$ due to the $v(\mathrm{C}=\mathrm{N})$ stretching vibrations. The absence of the $v(\mathrm{C}=\mathrm{O})$ bands in the spectra of complexes $\mathbf{1}$ and $\mathbf{2}$ suggests the enolization of the amide functionality upon coordination to the metal atoms. For the spectrum of complex 3 typical band for $v(\mathrm{C}=\mathrm{O})$ indicates that the carbonyl group is free. The typical bands for the nitrate ligand for complex $\mathbf{3}$ are observed at 1456,1311 and $1072 \mathrm{~cm}^{-1}$, and that for the azide anion is at $2072 \mathrm{~cm}^{-1}$.

\section{3. Structure Description of Complex 1}

The structure of complex $\mathbf{1}$ is presented in Figure 1. The asymmetric unit comprises of a cobalt complex molecule, two methanol molecules and one water molecule. The coordination sphere of the Co atom is a distorted octahedral, with the tridentate hydrazone ligands coordinated in a meridional mode, generating five membered chelate rings with angles in the range 82.26(16)$83.04(17)^{\circ}$. The coordinate bond angles are within normal values. ${ }^{9}$ The hydrazone coordinates to the Co atom with the pyridine nitrogen, enolate oxygen and imino nitrogen atoms. Ligand $\mathrm{L}$ is nearly coplanar, with the dihedral angles between the benzene and pyridine rings of 10.7(5) and $13.2(5)^{\circ}$, respectively. The bond lengths are similar to the cobalt complexes containing the enolate form of this ligand type..$^{5,10,11}$ 


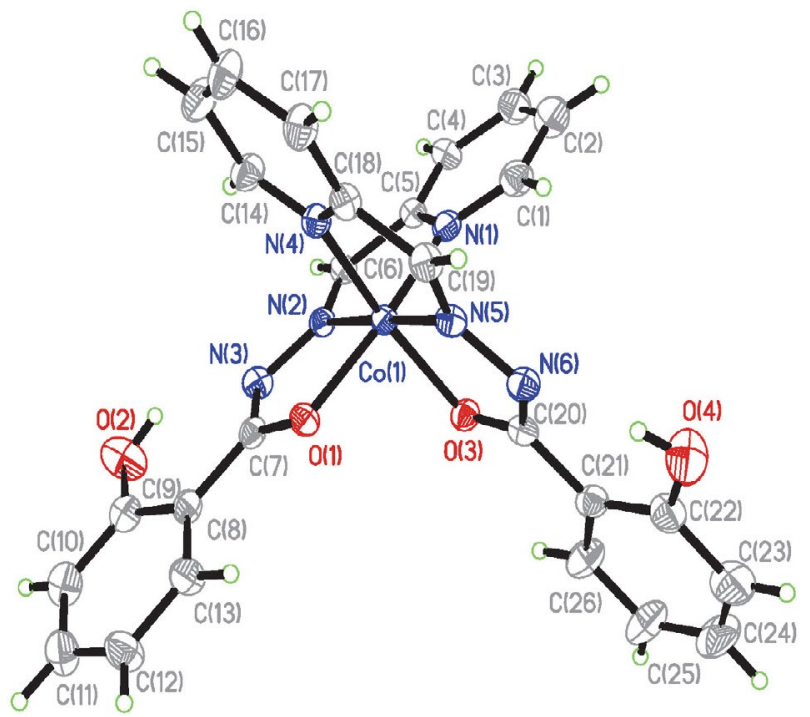

Figure 1. A perspective view of complex 1 with the atom labeling scheme. Thermal ellipsoids are drawn at the $30 \%$ probability level.

\section{4. Structure Description of Complex 2}

The structure of complex $\mathbf{2}$ is presented in Figure 2. The coordination sphere of the $\mathrm{Zn}$ atom is a distorted octahedral, with the tridentate hydrazone ligands coordinated in a meridional mode, generating five membered chelate rings with angles in the range 74.78(10)-75.49(9) ${ }^{\circ}$. The coordinate bond angles are within normal values. ${ }^{12}$ The hydrazone coordinates to the $\mathrm{Zn}$ atom with the pyridine nitrogen, imino nitrogen and enolate oxygen atoms. Ligand $\mathrm{L}$ is somewhat deviated from planarity, with dihedral angles between the benzene and pyridine rings of 19.1(6) and $11.1(6)^{\circ}$, respectively. The bond lengths are similar to the zinc complexes containing the enolate form of this ligand type. ${ }^{12,13}$

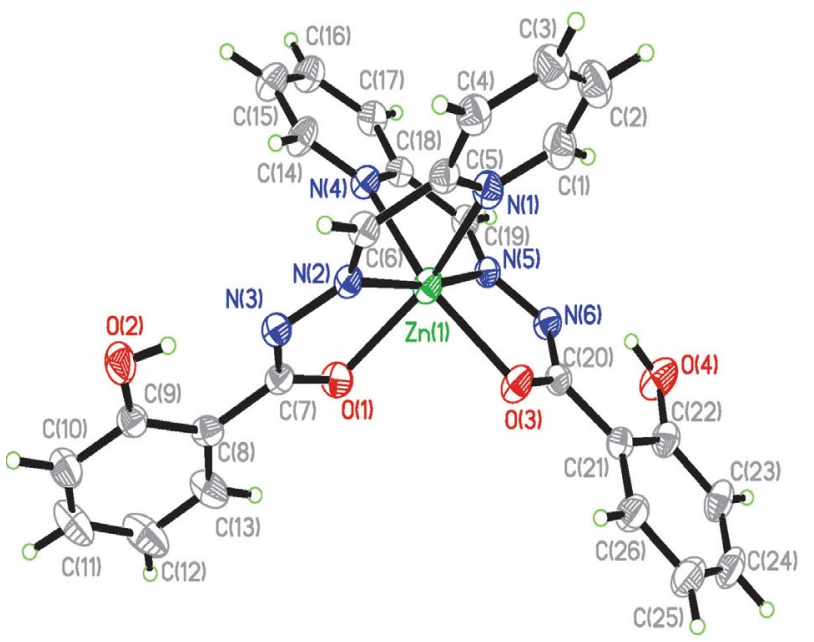

Figure 2. A perspective view of complex 2 with the atom labeling scheme. Thermal ellipsoids are drawn at the $30 \%$ probability level.

\section{5. Structure Description of Complex 3}

The structure of complex 3 is presented in Figure 3. The asymmetric unit comprises of a cadmium complex cation and an azide anion. The cadmium complex cation possesses a crystallographic two-fold rotation axis symmetry, with the axis passing through the line of $\mathrm{Cd}(1)-$ $\mathrm{N}(4)-\mathrm{O}(4)$. The coordination sphere of the $\mathrm{Cd}$ atom can be described as a severely distorted octahedral, with the bidentate hydrazone ligands coordinated in a meridional mode, generating five a membered chelate ring with angle of $67.7(2)^{\circ}$. The coordinate bond angles are within normal values. ${ }^{14}$ The hydrazone coordinates to the $\mathrm{Cd}$ atom through the pyridine nitrogen, imino nitrogen and enolate oxygen atoms. Hydrazone ligand is nearly coplanar, with dihedral angles between the benzene and pyridine rings of $7.9(5)^{\circ}$. The nitrate ligand coordinates to the $\mathrm{Cd}$ atom through two oxygen atoms. The coordinate bond lengths are comparable to the cadmium complexes containing this ligand type. ${ }^{14,15}$

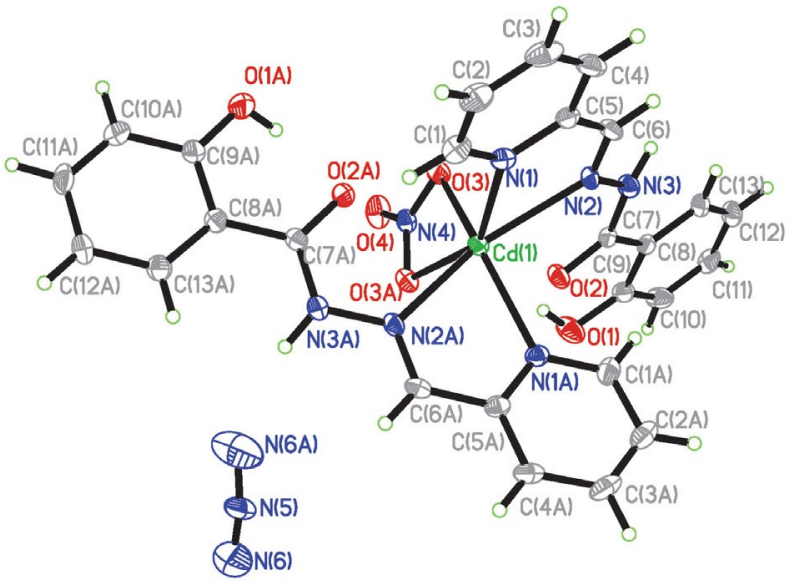

Figure 3. A perspective view of complex 3 with the atom labeling scheme. Thermal ellipsoids are drawn at the $30 \%$ probability level.

\section{6. Antibacterial Activity}

The MIC (Minimum Inhibitory Concentration, $\mu \mathrm{g}$ $\mathrm{mL}^{-1}$ ) values of the compounds were determined by a colorimetric method using the dye MTT. ${ }^{16} \mathrm{HL}$ and the three complexes were screened for antibacterial activities against two Gram (+) bacterial strains (B. subtilis and $S$. aureus) and two Gram (-) bacterial strains (E. coli and $P$. fluorescence). The MIC values of the compounds against four bacteria are listed in Table 3. Penicillin G was used as a reference. The hydrazone HL has medium activity against $S$. aureus, weak activity against $B$. subtilis, and no activity against $E$. coli and $P$. fluorescence. The complexes have in general stronger activities against the bacterial strains than the free hydrazone. Complex 1 has strong activity against $B$. subtilis and $S$. aureus, and weak activity against $E$. coli and P. fluorescence. Complex 2 has medium 
activity against $B$. subtilis and $S$. aureus, weak activity against $P$. fluorescence, and no activity against $E$. coli. Complex $\mathbf{3}$ has strong activity against all the bacterial strains. The MIC values of complex 3 on B. subtilis and $S$. aureus are 2.3 and $1.2 \mu \mathrm{g} \mathrm{mL}^{-1}$, which are better than penicillin G. However, the free hydrazone and the complexes have no activity against two fungal strains Candida albicans and Aspergillus niger.

Table 3. Antimicrobial activities of the compounds

\begin{tabular}{lcccc}
\hline \multicolumn{5}{c}{ Minimum inhibitory concentrations $\left(\mu \mathrm{g} \mathrm{mL}^{\mathbf{- 1}}\right)$} \\
\hline $\begin{array}{l}\text { Tested } \\
\text { material }\end{array}$ & B. subtilis & S. aureus & E. coli & $\begin{array}{c}\boldsymbol{P} \text {. } \\
\text { fluorescence }\end{array}$ \\
\hline $\mathrm{HL}$ & 37.5 & 18.8 & $>150$ & $>150$ \\
$\mathbf{1}$ & 4.7 & 9.4 & 37.5 & 37.5 \\
$\mathbf{2}$ & 18.8 & 18.8 & $>150$ & 37.5 \\
$\mathbf{3}$ & 2.3 & 1.2 & 9.4 & 4.7 \\
Penicillin G & 2.3 & 4.7 & $>150$ & $>150$ \\
DMSO & $>150$ & $>150$ & $>150$ & $>150$ \\
\hline
\end{tabular}

\section{Conclusion}

In summary, three new cobalt(II), zinc(II) and cadmium(II) complexes derived from 2-hydroxy- $N$ '-(pyridin-2-ylmethylene)benzohydrazide were prepared and structurally characterized. The metal atoms in the complexes are in octahedral coordination. The cobalt and cadmium complexes have effective antibacterial activities against Bacillus subtilis, Staphylococcus aureus, Escherichia coli, and Pseudomonas fluorescence.

\section{Supplementary Material}

CCDC 1875732 (HL), 1875733 (1), 1875734 (2), and 1875735 (3) contain the supplementary crystallographic data for this paper. These data can be obtained free of charge at http://www.ccdc.cam.ac.uk/const/retrieving.html or from the Cambridge Crystallographic Data Centre (CCDC), 12 Union Road, Cambridge CB2 1EZ, UK; fax: +44(0)1223-336033 or e-mail: deposit@ ccdc.cam.ac.uk.

\section{Acknowledgments}

This work was financially supported by K.C. Wong Magna Fund in Ningbo University, Ningbo Natural Science Fund (Project no. 201701HJ-B01019) and College Students of Science and Technology Innovation Projects in Zhejiang province and Ningbo city (Project no. 2017R405008 and 2017YZD001).

\section{References}

1. (a) U. P. Singh, H. R. Bhat, A. Verma, M. K. Kumawat, R. Kaur, S. K. Gupta, R. K. Singh, RSC Advances 2013, 3, 17335-17348; DOI:10.1039/c3ra41604f

(b) F. Zhi, N. Shao, Q. Wang, Y. Zhang, R. Wang, Y. Yang, J. Struct. Chem. 2013, 54, 148-154;

DOI:10.1134/S0022476613010216

(c) S. Naseem, M. Khalid, M. N. Tahir, M. A. Halim, A. A. C. Braga, M. M. Naseer, Z. Shafiq, J. Mol. Struct. 2017, 1143, 235-244. DOI:10.1016/j.molstruc.2017.04.093

2. (a) C. Loncle, J. M. Brunel, N. Vidal, M. Dherbomez, Y. Letourneux, Eur. J. Med. Chem. 2004, 39, 1067-1071; DOI:10.1016/j.ejmech.2004.07.005

(b) E. N. Nfor, A. Husian, F. Majoumo-Mbe, I. N. Njah, O. E. Offiong, S. A. Bourne, Polyhedron 2013, 63, 207-213.

DOI:10.1016/j.poly.2013.07.028

3. (a) H. F. He, X. Y. Wang, L. Q. Shi, W. Y. Yin, Z. W. Yang, H. W. He, Y. Liang, Bioorg. Med. Chem. Lett. 2016, 26, $3263-$ 3270; DOI:10.1016/j.bmcl.2016.05.059

(b) R. M. Mohareb, D. H. Fleita, O. K. Sakka, Molecules 2011, 16, 16-27; DOI:10.3390/molecules 16010016

(c) H.-Q. Chang, L. Jia, J. Xu, W.-N. Wu, T.-F. Zhu, R.-H. Chen, T.-L. Ma, Y. Wang, Z.-Q. Xu, Trans. Met. Chem. 2015, 40, 485-491; DOI:10.1007/s11243-015-9938-x

(d) D. A. Megger, K. Rosowski, C. Radunsky, J. Kosters, B. Sitek, J. Muller, Dalton Trans. 2017, 46, 4759-4767;

DOI:10.1039/C6DT04613D

(e) L. M. Wang, S. J. Zhao, G. L. Bao, Y. Zhang, S. C. Xi, G. L. Zhou, X. Zhai, P. Gong, Med. Chem. 2016, 12, 621-630.

DOI:10.2174/1573406412666160106154551

4. (a) P. Bera, P. Brandao, G. Mondal, H. Jana, A. Jana, A. Santra, P. Bera, Polyhedron 2017, 134, 230-237;

DOI:10.1016/j.poly.2017.06.024

(b) R. R. Zaky, K. M. Ibrahim, I. M. Gabr, Spectrochim. Acta A 2011, 81, 28-34;

(c) M. V. Angelusiu, S. F. Barbuceanu, C. Draghici, G. L. Almajan, Eur. J. Med. Chem. 2010, 45, 2055-2062.

DOI:10.1016/j.ejmech.2010.01.033

5. P. Zhou, Y.-G. Zhao, Y. Bai, K.-L. Pang, C. He, Inorg. Chim. Acta 2007, 360, 3965-3970. DOI:10.1016/j.ica.2007.05.038

6. Bruker, SMART (Version 5.625) and SAINT (Version 6.01). Bruker AXS Inc., Madison, Wisconsin, USA, 2007.

7. G. M. Sheldrick, SADABS. Program for Empirical Absorption Correction of Area Detector, University of Göttingen, Germany, 1996.

8. G. M. Sheldrick, Acta Crystallogr. 2015, A71, 3-8. DOI:10.1107/S2053273314026370

9. (a) S. Chandra, A. K. Sharma, J. Coord. Chem. 2009, 62, 36883700; DOI:10.1080/00958970903121305

(b) S. S. Massoud, F. A. Mautner, Inorg. Chim. Acta 2005, 358, 3334-3340. DOI:10.1016/j.ica.2005.05.007

10. B. Samanta, J. Chakraborty, S. Shit, S. R. Batten, P. Jensen, J. D. Masuda, S. Mitra, Inorg. Chim. Acta 2007, 360, 2471-2484. DOI:10.1016/j.ica.2006.12.019

11. (a) M. Mishra, K. Tiwari, S. Shukla, R. Mishra, V. P. Singh, Spectrochim. Acta A 2014, 132, 452-464;

Wang et al.: Synthesis, Characterization and Crystal Structures of ... 
DOI:10.1016/j.saa.2014.05.007

(b) A. Sousa-Pedrares, N. Camina, J. Romero, M. L. Duran, J. A. Garcia-Vazquez, A. Sousa, Polyhedron 2008, 27, 33913397. DOI:10.1016/j.poly.2008.08.011

12. (a) P. Singh, D. P. Singh, V. P. Singh, Polyhedron 2014, 81, 56-65; DOI:10.1016/j.poly.2014.05.066

(b) P. Domiano, C. Pelizzi, G. Predieri, Polyhedron 1984, 3, 281-286; DOI:10.1016/S0277-5387(00)88108-5

(c) B. Samanta, J. Chakraborty, S. Shit, S. R. Batten, P. Jensen, J. D. Masuda, S. Mitra, Inorg. Chim. Acta 2007, 360, 24712484. DOI:10.1016/j.ica.2006.12.019

13. (a) S. Konar, A. Jana, K. Das, S. Ray, S. Chatterjee, S. K. Kar, Polyhedron 2012, 47, 143-150;

DOI:10.1016/j.poly.2012.07.080

(b) C.-F. Chow, S. Fujii, J.-M. Lehn, Chem. Asian J. 2008, 3, 1324-1335; DOI:10.1002/asia.200800101 (c) D.-L. Peng, N. Sun, Acta Chim. Slov. 2018, 65, 895-901. DOI:10.17344/acsi.2018.4543

14. F. X. Shen, W. Huang, X. C. Huang, S. Peng, D. Y. Wu, Transit. Met. Chem. 2015, 40, 681-689.

DOI:10.1007/s11243-015-9962-x

15. (a) K. Das, S. Konar, P. Pal, A. Jana, S. Chatterjee, S. Mukhopadhyay, Polyhedron 2015, 85, 172-180;

DOI:10.1016/j.poly.2014.08.043

(b) F. A. Afkhami, A. A. Khandar, G. Mahmoudi, W. Maniukiewicz, J. Lipkowski, J. M. White, R. Waterman, S. Garcia-Granda, E. Zangrando, A. Bauza, A. Frontera, CrystEngComm 2016, 18, 4587-4596. DOI:10.1039/C6CE00877A

16. J. Meletiadis, J. F. G. M. Meis, J. W. Mouton, J. P. Donnelly, P. E. Verweij, J. Clin. Microbiol. 2000, 38, 2949-2954.

\section{Povzetek}

Tri nove spojine, in sicer kobaltov(II), cinkov(II) in kadmijev(II) kompleks $\left[\mathrm{CoL}_{2}\right] \cdot 2 \mathrm{CH}_{3} \mathrm{OH} \cdot \mathrm{H}_{2} \mathrm{O}(\mathbf{1}),\left[\mathrm{ZnL}_{2}\right](\mathbf{2})$ in $\left[\mathrm{Cd}(\mathrm{HL})_{2}\left(\mathrm{NO}_{3}\right)\right] \mathrm{N}_{3}(3)$ smo sintetizirali z uporabo 2-hidroksi-N'-(piridin-2-ilmetilen)benzohidrazida (HL) ter jih okarakterizirali z IR, UV-Vis in monokristalno rentgensko difrakcijo. Rentgenska analiza je razkrila, da so kompleksi enojedrne zvrsti s kovinskim ionom v oktaedrični koordinaciji. Hidrazonu in njegovim kompleksom smo določili tudi antibakterijske (Bacillus subtilis, Staphylococcus aureus, Escherichia coli, Pseudomonas fluorescence) in antimikotične (Candida albicans, Aspergillus niger) lastnosti. Kompleksi imajo izražene protibakterijske lastnosti.

Except when otherwise noted, articles in this journal are published under the terms and conditions of the Creative Commons Attribution 4.0 International License 